\title{
Agnieszka Trela
}

\section{Społeczno-kulturowe uwarunkowania egzystencji kobiet niepełnosprawnych w krajach arabskich i w Indiach}

Miscellanea Anthropologica et Sociologica 15/2, 109-120

2014

Artykuł został opracowany do udostępnienia w internecie przez Muzeum Historii Polski w ramach prac podejmowanych na rzecz zapewnienia otwartego, powszechnego i trwałego dostępu do polskiego dorobku naukowego i kulturalnego. Artykuł jest umieszczony w kolekcji cyfrowej bazhum.muzhp.pl, gromadzącej zawartość polskich czasopism humanistycznych i społecznych.

Tekst jest udostępniony do wykorzystania w ramach dozwolonego użytku. 
Miscellanea Anthropologica et Sociologica 2014, 15 (2): 109-120

Agnieszka Trela ${ }^{1}$

\section{Społeczno-kulturowe uwarunkowania egzystencji kobiet niepełnosprawnych w krajach arabskich i w Indiach}

Tożsamość kobiety jest determinowana oczekiwaniem odnoszącym się do ról, które w społeczeństwie będzie ona pełnić. Role te wynikają z kontekstu, w jakim w określonych kulturach osadzone jest pojmowanie kobiecości oraz wynikające z niej zadania, przez kobietę wykonywane. Istotne jest przy tym, że każda kultura nieco odmiennie definiuje zespół cech fizycznych, psychicznych i osobowościowych, dzięki którym kobieta spełnia nadany jej przez społeczne i kulturowe uwarunkowania wzorzec kobiecości. W kontekście egzystencji kobiety niepełnosprawnej w różnych kręgach kulturowych wyjaśnić trzeba, że pod pojęciem niepełnosprawności należy rozumieć taką niekorzystną sytuację, będącą wynikiem doznanego uszkodzenia ustroju lub nabytej albo wrodzonej dysfunkcji organizmu, w wyniku której ma miejsce znaczne ograniczenie lub uniemożliwienie wypełniania przez jednostkę ról społecznych przypisanych jej ze względu na płeć, wiek, czynniki społeczne bądź uwarunkowania kulturowe. Role kobiece w krajach arabskich oraz Indiach rozpatrywane poprzez pryzmat doznawanej niepełnosprawności dodatkowo utrudniają funkcjonowanie społeczne tych kobiet w ich kręgach kulturowych. Jest to wynikiem niemal pełnego podporządkowania kobiety mężczyźnie, na co dodatkowo nakładają się tradycje wynikające $\mathrm{z}$ wyznawanych religii, wyrażające się między innymi w deprecjacji kobiety z niepełnosprawnością na gruncie osobistym, zawodowym czy społecznym lub kulturowym.

Słowa kluczowe: niepełnosprawność, tożsamość, kobieta w kulturze wschodniej

Socio-cultural conditioning of existence of the disabled women in Arabic countries and in India

The identity of a woman is determined by her role and performance in a society. These roles result from her cultural context, which determines the notion of femininity. Each culture defines the group of physical, psychical and personality features associated with

1 Uniwersytet Jagielloński; agtrela@o2.pl. 
femininity a little differently. In the context of disabled women, cultures explain the notion of disability differently. Disability is observed as an unfavourable condition, which results from an impaired organism or an acquired or congenital dysfunction of the organism and leads to a notable limitation or impossibility to fulfill the social roles connected to gender, age, and/or other social factors or cultural determinants. In Arab countries and India, disabilities make it difficult for women to perform the social functions of their gender in their cultures. This is the result of nearly complete submission of women to the men. Additionally, the religious traditions further depreciate disabled women in their personal, occupational, social and cultural circles.

Key words: disability, identity, woman in an Orient culture

Odnosząc się do definicji kultury, należy zwrócić uwagę, że istnieje wiele określeń tego pojęcia, używanego w najróżniejszych kontekstach. Jest to wynik stosowania tego terminu w zbliżonych, jednakże różniących się od siebie sytuacjach. Słowo kultura pochodzi z łaciny, gdzie oznacza uprawę; źródła historyczne po raz pierwszy przypisują użycie tego słowa w obecnym znaczeniu Cyceronowi, mówiącemu o uprawie umysłu (cultura aminii). Filozof miał na myśli kształcenie, usprawnianie ludzkiego myślenia i działania oraz intensyfikowanie wewnętrznej, duchowej aktywności człowieka. Znacznie później, w XIX wieku, pod pojęciem kultury zdaniem Lintona rozumiano „społeczne dziedzictwo społeczeństwa”, a współcześnie jako kulturę należy traktować „świadome, społecznie przekazywane dziedzictwo wytworów, wiedzy przekonań, wartości i oczekiwań normatywnych, które pomaga członkom danego społeczeństwa radzić sobie z pojawiającymi się problemami" (Goodman 1997: 37). Obecnie w naukach społecznych pod pojęciem kultury rozumie się zarówno materialne, jak i duchowe wytwory kultury człowieka od starożytności do chwili obecnej, historycznie ukształtowane wartości, zasady i normy koegzystencji ludzi (Januszek, Sikora 1997: 75-77). W często spotykanym ujęciu termin kultura definiowany jest jako na swój sposób złożona całość doświadczeń, wiedzy, wierzeń, sztuki, prawa, zasad moralnych, norm obyczajowych, a także wszelkich innych niewymienionych tu zdolności i nawyków, które człowiek nabywa poprzez socjalizację pośród otaczających go ludzi (Kłoskowska 1983: 19).

Kultura przyczynia się więc do warunkowania jednostki do określonych zachowań w pewnym kręgu obyczajowym, cywilizacyjnym czy kulturowym; tak też są kształtowane przekonania i sposoby postrzegania siebie w otoczeniu oraz oddziaływania środowiska. Kultura w tym przypadku stanowi bazową część składową prototypu osobowości w określonym kręgu cywilizacyjnym. Jest on odmienny prawie dla każdego regionu na świecie (Bajcar 2001: 49).

Powyższe określenie daje podstawę do uznania, że kultura jest płaszczyzną łączącą wiele rozmaitych, często odmiennych grup i społeczności poprzez wytwory ich sztuki, muzyki, myśli, idei. Dzięki temu, że obecnie następuje coraz szybszy przepływ informacji z miejsca, w którym dzieje się coś interesującego, do 
osób nimi zainteresowanych, faktem bezsprzecznym wydaje się upowszechnianie określonych zjawisk w odbiorze dużych grup ludzi.

Jednakże z przeprowadzonych badań psychologicznych oraz socjologicznych wynika wprost, że w wielu rozmaitych, często bardzo odległych od siebie kulturach, dominuje jeden, niezwykle przejmujący oraz niepozostawiający złudzeń co do swego charakteru, obraz społeczeństwa, w którym kobieta jest ściśle podporządkowana mężczyźnie, pełniąc wobec niego służebną rolę i nie mając żadnego wpływu ani na sytuację siebie samej, ani też rzeczywistość, w której funkcjonuje. Jest to patriarchalny model współfunkcjonowania dwóch płci, w wielu przypadkach uwarunkowany obowiązującymi w przeszłości oraz w chwili obecnej „przywilejami” wynikającymi z panujących kanonów religijnych.

Obowiązujące w wielu współczesnych krajach demokratyczne zasady funkcjonowania społecznego niejednokrotnie nie znajdują przełożenia w niwelowaniu kulturowych uwarunkowań różnic występujących w zawodowych, społecznych czy obyczajowych pozycjach kobiet i mężczyzn. Ma to swoje odzwierciedlenie zarówno w dostępie do systemu edukacyjnego, rynku pracy, jak i najpowszechniejszych zachowań społecznych. W wielu religiach, a właściwie w ich interpretacjach, pojawia się „tradycja”, według której kobieta, jako matka, powinna pełnić rolę opoki uczuciowej rodziny, co jednak tym samym wprost predestynuje tak postrzeganą kobietę do skupiania się wyłącznie na trwaniu rodziny i jej prawidłowym funkcjonowaniu. Wszystkie inne działania, w tym takie, które mogłyby godzić w rolę macierzyńską lub ją zaburzać, winny być (zgodnie z tak rozumianą tradycją) eliminowane. Wprost prowadzi to do uzasadnionej tezy, że przypisanie kobiecie wyłącznie roli macierzyńskiej $\mathrm{w}$ znaczącym stopniu uniemożliwia jej jakiekolwiek inne, niezwiązane z prowadzeniem domu, zachowania (Grzesiak 2011: 126-127).

Należy przy tym mieć na uwadze, że w tak ukształtowanym społeczeństwie sama kobieta jest wychowywana i uwarunkowywana do wypełniania określonej roli, przypisanej i wynikającej z płci, co w dużej mierze decyduje o jej tożsamości, określanej społecznymi oczekiwaniami wobec ról przez tę kobietę pełnionych lub wynikających z funkcjonowania w konkretnej zbiorowości czy społeczności. Oczekiwania te są zbieżne najczęściej ze stereotypowym wyobrażeniem ról kobiecych, nabywanych przez nie w procesie socjalizacji. Zgodnie z tym wyróżnia się ogólny stereotyp kobiety, według którego jest ona źródłem wsparcia dla innych osób (w tym członków jej najbliższej rodziny), dba o rodzinę, opiekując się dziećmi.

W wielu kulturach zwanych potocznie „tradycyjnymi”, występujących chociażby w większości krajów muzułmańskich w Azji czy w Afryce, sprawą oczywistą jest „władza” mężczyzny nad kobietą (wskazująca wprost na uzurpowanie sobie przez mężczyznę prawa do decydowania o wszystkim, co dotyczy kobiety) czy też niemożliwość występowania przez kobietę jako podmiotu jakichkolwiek sytuacji społecznych i zawodowych. Poza tym w kulturach, w których deprecjonowanie kobiety jako równorzędnego partnera mężczyzny jest już tradycją, obowiązujący wzorzec społeczny przedstawia zdecydowany prymat męskości, tak w sprawach 
zawodowych, jak życia kulturowego lub też obyczajowości. O wiele rzadszy, szczególnie w krajach uznawanych za tradycyjne, jest udział kobiet w którymkolwiek $\mathrm{z}$ wymienionych pól działalności człowieka. Wiąże się to przede wszystkim z obrządkami religijnymi, determinującymi całą kulturę określonych grup społecznych, ale także $\mathrm{z}$ nierozerwalnym oddziaływaniem religii na ludzi $\mathrm{w}$ pewnych uwarunkowaniach instytucjonalnych (Boski 2006: 19-23). W takich uwarunkowaniach kobieta jest postrzegana jako kapłanka domowego ogniska, podczas gdy mężczyzna odpowiada za utrzymanie rodziny pod względem materialnym oraz ponosi odpowiedzialność w zakresie wsparcia kobiety i całej rodziny w trudnych momentach życiowych.

\section{Kobieta z niepełnosprawnością w Indiach}

Podstawą do kreowania i ugruntowywania określonych ról społecznych, przypisanych poszczególnym płciom, a także stosunku do braku sprawności w wielu przypadkach determinują kanony religijne. Przykładowo, w hinduizmie z cyklicznym obrazem świata łączy się nauka o reinkarnacji, czyli ponownych narodzinach i działaniu prawa karmana (Kościelniak 2006: 73). Prawo to, wyraźnie zauważalne w hinduizmie, statuuje ideę reinkarnacji, zgodnie z którą człowiek w każdym swym kolejnym wcieleniu ponosi konsekwencje swoich uprzednich, dobrych i złych, uczynków.

Układ społeczny, jaki determinuje życie wyznawców hinduizmu, jest systemem kast, czyli zamkniętych grup społecznych i religijnych związanych z przyjściem na świat w określonej rodzinie. Najważniejsze kasty to Bramini, czyli kapłani, wojownicy zwani Kszatrija, chłopi i mieszczanie, czyli stan średni zwany Wajśja i stan służebny zwany Siudra. Wszystkie jednostki, które nie mieszczą się w systemie kastowym, są określane mianem pariasów, czyli nietykalnych i nieczystych (Abgrall 2005: 56).

Najważniejszymi pojęciami etyki hinduizmu są działanie, czyli karma, i obowiązek, czyli dharma. Hindusi wyznają wiarę w prawa moralne, które przejawiają się we wszechświecie poprzez działanie jednostki, determinowane wpływem bogów. Jeżeli jednostka zachowuje się w sposób godny, zgodny z karmą, będzie za to nagrodzona przy powtórnych narodzinach (reinkarnacji). Istnieją również prawa obowiązujące wszystkich bez wyjątku, a więc bez względu na kastę, do której przynależą, oraz takie, które odnoszą się wyłącznie do poszczególnych kast. Poprzez pewne praktyki religijne oraz wyznawany kult, praktykujący hinduizm mogą pozyskać dobrą karmę. Gromadzenie karmy jest sposobem na realizowanie kolejnych stopni wtajemniczenia w przeżywanej wierze (Kościelniak 2006: 75). Kulturę Indii cechuje wysoka współzależność, przejawiająca się w wychowaniu w grupach, kastach czy też klasach lub społecznościach religijnych, których częścią stają się jej członkowie. $\mathrm{W}$ ten sposób przejawia się kolektywizm. Z pojęciem kolektywizmu związane są badania Geerta Hofstede, który udowodnił, że 
jednym $\mathrm{z}$ wymiarów istnienia i funkcjonowania jednostki ludzkiej w grupie jest podporządkowanie regułom jej działania lub brak tego podporządkowania. Hofstede zauważył, że im bardziej indywidualistycznie kreowana jest kultura danego społeczeństwa, tym bardziej sukces jednostki jest tam postrzegany jako wartość sama w sobie. Natomiast na przeciwległym biegunie znajdują się kultury kolektywistyczne, w których całe życie i funkcjonowanie człowieka jest podporządkowane sukcesowi grupy (klasy, kasty), do której on należy (Kwiatkowska, Grzymała-Moszczyńska 2008: 462). W społeczności hinduskiej, na wskroś głęboko kolektywistycznej, oparcie znajduje takie postrzeganie kobiety niepełnosprawnej, traktowanej zawsze jako istota „gorszego rodzaju”, która przez swoją „niepełną wartość", wynikającą z doznawanej niepełnosprawności, nie może przeciwstawiać się decyzjom mężczyzny.

Społeczność hinduska jest zorganizowana w porządku patriarchalnym, co oznacza podrzędną rolę kobiety w stosunku do mężczyzny. Podporządkowanie to wynika między innymi ze zbioru praw społecznych, spisanych jeszcze w epoce klasycznej przez uratowanego z potopu dzięki boskiej interwencji strażnika porządku na świecie - Manu. Zgodnie z tymi prawami rolą kobiety jest trwać przy mężczyźnie, co oznacza wspieranie go, zajmowanie się domem rodzinnym i dziećmi, a nie pracą zawodową czy inną aktywnością społeczną (Kosakowska 2006: 96-97).

Niestety, zgodnie z tradycją kobieta hinduska uzależnia swoje życie od rodziny, $\mathrm{z}$ tego też względu zobligowana jest przede wszystkim do podporządkowania go rodzinie (w dosłownym tego słowa znaczeniu), czyli dzieciom i mężowi. Oczywiście, zdarzają się przypadki poszukiwania przez wyemancypowane kobiety własnej drogi życiowej, jednak nadal są to sytuacje z rzadka występujące. $Z$ tradycji wynika, że to mężczyzna dominuje w grupie społecznej, a kobieta jest mu całkowicie podporządkowana. $Z$ drugiej strony, mass media i związany $\mathrm{z}$ nimi dostęp do informacji pokazują młodym kobietom, że można być samodzielną, niezależną, a zarazem realizującą się w szczęściu rodzinnym, a także pracy zawodowej. Z tak dokonującego się ścierania nowoczesności z tradycją wynikają bardzo powoli dokonujące się zmiany wizerunku kobiety, niebędącej już tylko boginią-opiekunką ogniska domowego, bezwzględnie tym rolom podporządkowaną, ale mogącej jednocześnie realizować się zawodowo czy społecznie.

Mimo nieuchronnie dokonującej się ewolucji pozycji kobiety w społeczeństwie nadal w powszechnym ujęciu jest utrwalony jej wizerunek jako istoty słabszej, podległej mężczyźnie i wymagającej opieki. Należy jednak mieć na uwadze, że kultura indyjska zawiera dwa niewiele zbliżone do siebie wzorce postaci kobiecych, z których jedna jest dynamiczna, kreatywna, samowystarczalna i silna, walcząca z przeciwnościami losu i samodzielnie kierująca swoim życiem. Drugi model natomiast statuuje kobietę jako istotę w pełni uzależnioną od mężczyzny, wymagającą jego stałej opieki i wsparcia, wręcz ubezwłasnowolnioną. Niestety, ów drugi model nadal przeważa, a za jego upowszechnieniem stoi religia 
indoaryjska, niezwykle powszechna w głównym nurcie religii hinduistycznej (Jakubczak 2005: 12-14).

W takiej sytuacji nie może być żadnym zaskoczeniem, że pozycja osoby niepełnosprawnej, a zwłaszcza kobiety $\mathrm{z}$ dysfunkcjami zdrowotnymi jest jeszcze słabsza, niż gdyby rozpatrywać ją wyłącznie na kanwie płci. Dodać przy tym należy, iż jeszcze na początku lat 90. ubiegłego wieku sytuacja niepełnosprawnych w Indiach była bardzo zła. Liczba osób z różnymi dysfunkcjami wynosiła około $60 \mathrm{mln}$ osób, co stanowiło prawie $6 \%$ liczby wszystkich mieszkańców, a przy tym zaledwie niecałe $2 \%$ dzieci (niepełnosprawnych) objętych było obowiązkiem szkolnym. Z kolei odsetek zatrudnionych wśród osób niepełnosprawnych oscylował wokół $1 \%$. Blisko połowa niepełnosprawnych cierpi na wady wzroku; od 5,8\% do $16,6 \%$ ma wady słuchu; od 7,5\% do $11,7 \%$ charakteryzują wady wymowy, a od 27,9\% do 57,5\% cierpi z powodu wad narządu ruchu (Grzesiak 2011: 129).

Dopiero w 1995 roku uchwalono ustawę o osobach z niepełnosprawnością (równe szanse, ochrona praw i pełne uczestnictwo w życiu społecznym). Od tego momentu można mówić o realizowanej w praktyce integracji, równości oraz poszanowaniu praw osób z niepełnosprawnością. Trzy lata później zostały opracowane dwa programy edukacyjne o kolosalnym, jak się wydaje, znaczeniu dla zasady integracji niepełnosprawnych w społeczeństwie hinduskim. Pierwszy z nich to „Przygotowanie nauczycieli do nauczania specjalnego”, którego celem było przekazanie nauczycielom umiejętności pracy z uczniami o specjalnych potrzebach. Drugi nosi nazwę „Szkolnictwo wyższe dla osób ze specjalnymi potrzebami”. W ramach tej inicjatywy utworzono oddziały dla niepełnosprawnych na uniwersytetach oraz w collegeach oraz zlikwidowano bariery architektoniczne i zapewniono specjalistyczny sprzęt dla studentów $z$ niepełnosprawnością. Dzięki tym działaniom, a także innym, wdrażanym przez główne siły polityczne kraju, ustalono, że do roku 2020 system edukacyjny zostanie dostosowany w pełni do potrzeb osób z niepełnosprawnością. Poza walką z barierami społecznymi zostały podjęte także działania służące znoszeniu barier architektonicznych, utrudniających normalne funkcjonowanie niepełnosprawnym $\mathrm{z}$ ograniczeniami ruchowymi. Natomiast wybory powszechne w 2004 roku pozwoliły sprawdzić działanie maszyn do głosowania dla niewidzących, obsługiwanych alfabetem Braille’a. Powyższe działania doprowadziły do ratyfikowania w październiku 2007 roku przez Indie Konwencji ONZ o prawach osób z niepełnosprawnością (Abidi 2009: 11-15).

Jednym z najważniejszych wymiarów funkcjonowania kobiet niepełnosprawnych w społeczeństwie hinduskim jest doznawana przez nie przemoc seksualna i fizyczna, doświadczana przez znaczny odsetek tej części społeczeństwa hinduskiego. Kobiety $\mathrm{z}$ niepełnosprawnością intelektualną $\mathrm{w}$ Indiach są narażone na przemoc seksualną, w tym gwałty (25\%); w odniesieniu do kobiet $\mathrm{z}$ niepełnosprawnością fizyczną zagrożenie wynosi 13\%; prawie 50\% niepełnosprawnych intelektualnie kobiet zagrożonych jest przemocą fizyczną; natomiast $\mathrm{w}$ odniesieniu do kobiet niepełnosprawnych fizycznie (w tym z deficytami wzroku i słuchu) - są one narażone w 22\% przypadków na przemoc fizyczną (Grzesiak 2011: 132). 
Można wręcz sformułować tezę, że kobiety niepełnosprawne w Indiach doświadczają podwójnej niepełnosprawności, gdyż nie tylko mają znacząco niższą pozycję społeczną od mężczyzn, ale też doświadczana niepełnosprawność w ogromnej mierze deprecjonuje je w percepcji społecznej.

Zgodnie z koncepcją wyrażaną w hinduizmie niepełnosprawność jest postrzegana jako kara za grzechy popełnione w minionym wcieleniu człowieka. Równie powszechne jest przekonanie, że niepełnosprawność potomstwa jest wynikiem złych słów wypowiedzianych przez matkę w stronę dziecka („Wszystko to zdarzyło się, ponieważ przeklęłam je (dziecko). Gdyby było milsze wobec mnie, nie zrobiłabym tego" (Ghai 2011: 128)).

Znacząca część osób niepełnosprawnych w Indiach to kobiety. Ich sytuacja jest znacznie gorsza niż sytuacja chociażby kobiet sprawnych. W kraju, który jest współcześnie jednym z najdynamiczniej rozwijających się gospodarczo państw na świecie, wyraźnie zauważalna jest ta dychotomia, bowiem wysoko rozwinięte centra miast, takich jak Bombaj czy Delhi kontrastują ze slumsami, znajdującymi się na ich obrzeżach oraz terenami wiejskimi, które zamieszkuje największa część społeczeństwa. W każdych okolicznościach kobieta ma znacznie niższy status społeczny niż mężczyzna, który wiąże się z kulturowym aspektem osadzenia roli kobiecej whinduizmie. Co więcej, kobieta jest zawsze podporządkowana mężczyźnie, oczekującemu od niej wydania na świat potomka płci męskiej. Jeszcze gorsza jest sytuacja kobiety niepełnosprawnej, która nie może liczyć na wsparcie bliskich, a już w szczególności mężczyzny. Pojawienie się dziecka niepełnosprawnego jest ogromnym obciążeniem dla rodziny pod względem nie tylko psychicznym, ale i ekonomicznym. Dotyczy to w głównej mierze dziewczynek. Co prawda w Indiach z mocy prawa dzieci objęte są obowiązkiem szkolnym, jednak jest on niezwykle wybiórczo realizowany, głównie ze względu na sytuację ekonomiczną ludności. Natomiast w przypadku posiadania w rodzinie dziecka niepełnosprawnego, zwłaszcza dziewczynki, nie ma tak naprawdę możliwości wypełniania przez nie obowiązku szkolnego, bowiem zawsze na przeszkodzie staną perturbacje natury administracyjnej (np. brak odpowiedniego zaświadczenia lekarskiego). W efekcie dzieciom niepełnosprawnym pozostaje uczestniczenie w organizowanych przez rodziców pracach domowych, niemających zbyt wiele wspólnego $\mathrm{z}$ nauką realizowaną $\mathrm{w}$ szkole.

Sprawą nie mniej istotną od powyższego jest charakter oddziaływań wychowawczych i pielęgnacyjnych, świadczonych w placówkach przeznaczonych do opieki nad niepełnosprawnymi dziećmi, zlokalizowanych między innymi w Delhi oraz Bharuch, w których zatrudniona jest zbyt mała liczba wykwalifikowanego personelu, mającego w dodatku pod opieką ogromne ilości potrzebujących. Niewystarczająca jest także ilość wyspecjalizowanego sprzętu odpowiedniej jakości oraz osób go obsługujących (Grzesiak 2011: 131). Najważniejsze jednak jest to, że działaniom rehabilitacyjnym poddawani są przede wszystkim chłopcy, którzy ze względu na płeć charakteryzują się wyższym statusem społecznym niż niepełnosprawne dziewczęta. One natomiast wskutek wspomnianych inklinacji o wiele częściej pozostają w domu, pozbawione jakiejkolwiek specjalistycznej opieki. 
$\mathrm{Na}$ zakończenie rozważań dotyczących społeczno-kulturowych uwarunkowań funkcjonowania kobiet niepełnosprawnych w Indiach należy zwrócić uwagę na ciekawe wydarzenie, jakie miało miejsce w 2006 roku. Na peryferiach miasta Ahmedabad zorganizowano pokaz mody z udziałem ponad 30 niewidomych kobiet, które wcześniej wiele czasu poświęciły na opanowanie odpowiedniego układu choreograficznego, przez co nie odróżniały się od pełnosprawnych modelek uczestniczących w tym pokazie. W ten sposób zwrócono uwagę zarówno na fakt obecności w społeczeństwie hinduskim znaczącej liczby osób niepełnosprawnych, jak i ich praw do godnego życia.

\section{Kobieta z niepełnosprawnością w krajach arabskich}

Dominujący w krajach arabskich islam to religia, która powstała na terenie Półwyspu Arabskiego około siódmego wieku po Chrystusie. Stanowi konglomerat wierzeń arabskich, będących pochodną boskiego panteonu plemion nomadyjskich oraz zapożyczeń $\mathrm{z}$ innych ówczesnych kultur. $\mathrm{Z}$ tego też powodu $\mathrm{w}$ wierze islamskiej można doszukać się śladów religii Asyryjczyków, Bizantyjczyków, Aramejczyków, Fenicjan, Egipcjan oraz Hebrajczyków (Danecki 1997: 17). Kanony wiary islamskiej opierają się więc o wpływy innych wierzeń - judaistycznych czy indoirańskich, ale w Koranie można dostrzec także podobieństwa do chrześcijańskiego postrzegania świata oraz roli w nim Boga i ludzi (Walther 1982: 38). Muzułmanin kieruje się w życiu określonymi dogmatami, wypełniając przy tym obowiązki często wprost wynikające z Koranu. Dogmatami są: wiara w jednego Boga; anioły; pisma: Torę, Ewangelie, Koran; wysłanników Boga (od Adama do Mahometa) oraz Dzień Sądu Ostatecznego (Danecki 1997: 109-117). Postępowanie według owych boskich wskazówek prowadzi do spełnienia się muzułmanina w wierze.

Wyobrażenie życia w religii islamskiej opiera się o gloryfikowanie śmierci jako powrotu człowieka do Boga. Człowiek po to żyje, by u kresu tego życia, w trakcie Sądu Ostatecznego, być ocenionym przez Boga i dostąpić rozgrzeszenia lub zostać skazanym na wieczne zatracenie. W związku $\mathrm{z}$ tym to, jak spędzane jest życie doczesne, warunkuje, jak będzie wyglądało życie po śmierci.

Religia islamska inkorporowała patriarchat w swoje zwyczaje, a pozycja kobiety w rodzinie jest przede wszystkim odzwierciedleniem jej znaczenia dla trwania tej rodziny poprzez macierzyństwo. Potwierdził to sam Mahomet, wielokrotnie wskazując, że kobieta zarówno w zakresie dostępnych jej dóbr materialnych, jak i pełnionych ról społecznych jest wizytówką mężczyzny i tylko w ten sposób przysporzy mu właściwych zasług po śmierci. Inaczej mówiąc, mężczyzna jest przez wyznawaną przez siebie wiarę zobowiązany do zapewniania kobiecie opieki, środków do życia i takiego poziomu życia oraz zadowolenia z niego, który będzie potwierdzał jego status społeczny. $Z$ drugiej jednak strony nie należy zapominać, że jeszcze przed wprowadzeniem nauk koranicznych niejednokrotnie dochodziło do sytuacji, w której kobieta była traktowana jako pomocnica 
w domu mężczyzny i obiekt seksualnego zaspokojenia małżonka (Abu-Rub, Zabża 2002: 12). Sam Mahomet zmienił dotychczasowe pojmowanie związku małżeńskiego, wskazując własnymi słowami, że „Małżeństwo jest moją sunną. Ktokolwiek odrzuca moją sunnę, ten nie jest z nas" (Zyzik 2003: 34). Co prawda tradycja islamu wskazuje, że kobieta jest równa mężczyźnie, jednakże w praktyce nie jest to nakaz religijny, który byłby w pełni przestrzegany, przynajmniej w jego europeistycznym pojmowaniu, bowiem „równość" kobiety w świecie arabskim nie jest tożsama $z$ równością postrzeganą przez pryzmat europejski. Z punktu widzenia Koranu kobieta ma prawo dziedziczyć po bliskich, decydować o swoim małżeństwie, być osobą publiczną, zdobywać wykształcenie i pracować, niezależnie od męża czy męskich członków swej rodziny, gdy jest niezamężna. Dogmatycznie jednak traktowane jest (zgodnie z obowiązującym kanonem religijnym) uniezależnianie się kobiety od mężczyzny (domu rodzinnego), bowiem to mężczyźni właśnie są zobowiązani do zagwarantowania swej córce, siostrze, małżonce szczęścia, wyrażającego się w dobrym traktowaniu i zapewnieniu bytu ekonomicznego, co w efekcie sprowadza się do ograniczania prawa do samostanowienia kobiety (Abu-Rub, Zabża 2012: 27).

Niepełnosprawność w arabskiej kulturze bardzo często w powszechnym pojęciu jest kojarzona $z$ karą za sprzeniewierzenie się nakazom wiary, wynikającym z Koranu. Z tego też powodu w społecznościach arabskich rzadko można natknąć się na prawdziwe, to jest oparte na nauce, rozpoznanie i opisanie, a przede wszystkim rozumienie niepełnosprawności, co w dużej mierze przyczynia się do braku rzetelnych danych na temat liczby osób dotkniętych rozmaitymi ułomnościami oraz poszczególnych ich rodzajów. Dodatkowym elementem komplikującym sprawdzenie liczby osób niepełnosprawnych, składających się na którekolwiek ze społeczeństw państw arabskich, jest bardzo niski poziom rozwoju opieki medycznej. Wskutek tego ogromna większość osób, które rodzą się z określonymi deficytami rozwojowymi, po prostu umiera albo zaraz po urodzeniu, albo wkrótce po stwierdzeniu konkretnego schorzenia. Nie należy też zapominać i o tym, że w krajach arabskich, podobnie jak w Indiach, osoba jest uznawana za niepełnosprawną wtedy, gdy nie może wypełniać ciążących na niej obowiązków. $Z$ tego też powodu brak rzetelnych danych mogących ilustrować faktyczny poziom niepełnosprawności w krajach kultury islamskiej. Według rozbieżnych danych, podawanych przez instytucje statystyczne krajów Bliskiego Wschodu, około $10 \%$ do $12 \%$ populacji to osoby niepełnosprawne. Poza tym wiele rodzin, wychowywanych w tradycyjnej kulturze arabskiej, nie chce przyznawać się do posiadania $\mathrm{w}$ rodzinie osoby niepełnosprawnej, gdyż to obniża ich status społeczny (Helali 2009: 56).

Słabo rozwinięte kraje arabskie charakteryzują się między innymi tym, że niski status społeczny kobiety dodatkowo doznaje uszczerbku na skutek doświadczanej przez nią niepełnosprawności. Przyczynia się ona poza tym do i tak już niskiego dostępu do usług medycznych czy oświatowych, przez co znacznie większą liczbę kobiet niż mężczyzn dotkniętych niepełnosprawnością cechuje analfabetyzm. Można tu wręcz mówić o dyskryminacji, skoro w porównaniu do 
kobiet kilkunastokrotnie wyższy jest odsetek niepełnosprawnych mężczyzn wypełniających obowiązek szkolny.

Nie inaczej przedstawia się sytuacja kobiet niepełnosprawnych w krajach arabskich, jeżeli chodzi o dostęp do rynku pracy. Tu także notowane są kilkunastokrotnie wyższe odsetki pracujących mężczyzn niż kobiet, które ze względu na doznawane ograniczenia fizyczne lub intelektualne najczęściej zatrzymywane są w domu (Grzesiak 2011: 134).

Wydaje się naturalną konsekwencją wyznawanego porządku społecznego oraz kierujących nim kanonów wiary islamskiej, że związki małżeńskie inicjowane są przez mężczyzn, a nie przez kobiety; to oni także decydują, czy i kiedy w taki związek chcą wstąpić. Stąd też o wiele częściej właśnie mężczyźni charakteryzujący się jakąkolwiek niepełnosprawnością mają szansę na znalezienie życiowej partnerki, niż ma to miejsce w przypadku kobiet z niepełnosprawnością. Największe szanse na zawarcie związku małżeńskiego wśród nich mają te, które charakteryzują się niewielkimi ograniczeniami sprawności intelektualnej. Gwoli wyjaśnienia należy dodać, że nadal tradycją islamską jest zawieranie małżeństw między dalszymi lub bliższymi członkami tej samej rodziny. Takie bliskie pokrewieństwo może przyczyniać się do rozmaitych wad genetycznych, współodpowiedzialnych za wiele rodzajów niepełnosprawności.

W celu polepszenia obecnych warunków życia kobiet niepełnosprawnych w krajach arabskich najważniejsze wydaje się zwrócenie uwagi na dostępność edukacji oraz powszechnego systemu opieki zdrowotnej, gdyż tylko w takich okolicznościach kobieta niepełnosprawna nie będzie stygmatyzowana jako jednostka podlegająca wykluczeniu społecznemu.

Dobrze rozwinięte kraje arabskie charakteryzują się o wiele lepszym niż w innych regionach tego kręgu kulturowego statusem kobiet niepełnosprawnych. Między innymi w Zjednoczonych Emiratach Arabskich czy Omanie kobieta, mająca wyższy status społeczny, przejawiający się w łatwiejszym dostępie do edukacji, opieki zdrowotnej czy rynku pracy, nawet z niepełnosprawnością nie jest uważana za jednostkę gorszą. Wręcz przeciwnie, rozwinięty system opieki zdrowotnej i edukacji pozwala rozwijać się na miarę posiadanych przez te kobiety możliwości.

Porównując jednak wyjściowe pozycje kobiety w hinduizmie i w islamie, jasne staje się, że tylko w tym drugim wyznaniu kobieta została upodmiotowiona, co w praktyce hinduizmu wydaje się jeszcze odległym wydarzeniem. Dzieje się tak, gdyż indyjscy mężczyźni nadal w przeważającej większości (co potwierdza chociażby ugruntowywany w szeroko rozumianej rozrywce indyjskiej ideał kobiecy) traktują kobiety jako, owszem, obiekt uwielbienia, ale też własność.

W poruszanym w pracy kontekście znaczeniowym kobiecość i towarzysząca jej niepełnosprawność, zarówno w Indiach, jak i w krajach islamskich, w znaczącym stopniu definiują zjawisko eliminowania kobiet z życia innego niż wyłącznie poświęcone rodzinie i „ognisku domowemu”. Zajmując często niższą i słabszą pozycję niż mężczyzna, kobieta $\mathrm{z}$ niepełnosprawnością często jest odtrącana, pozostawiana samej sobie, bez prawa do normalnej egzystencji i funkcjonowania 
w społeczeństwie. Zjawisko owo wydaje się tym bardziej zaskakujące, że postępująca w Indiach maskulinizacja powinna sprzyjać szacunkowi i dbałości o kobietę jako „dobro rzadkie”, niezbędne dla zachowania prawidłowej kondycji społeczeństwa. Tymczasem odnotowywane jest wręcz odwrotne zachowanie, jeszcze mocniej podkreślające rozumienie roli kobiety wyłącznie przez pryzmat „dodatku do męża i rodziny".

W nieco odmienny sposób kształtuje się natomiast sytuacja kobiety z niepełnosprawnością w krajach islamskich, jednak (jak już wcześniej wskazano) jest ona uzależniona od regionu geograficznego, stopnia rozwoju cywilizacyjnego danej grupy społecznej i jej samoświadomości co do ról kobiety i mężczyzny, wynikających z nauki Koranu.

Żadnego jednak z opisywanych państw nie można, pod względem uczestnictwa niepełnosprawnych kobiet w życiu społecznym, zawodowym czy kulturalnym, porównywać z kulturą Zachodu, gdyż istnieje zbyt wiele odmienności, aby taka komparacja była możliwa. Rozważania o charakterze głównie kulturowym, ale także cywilizacyjne wprost wskazują, jak istotne są odmienności krajów Wschodu od krajów Zachodu, szczególnie w odniesieniu do sytuacji kobiet niepełnosprawnych.

Literatura

Abgrall J.M., 2005, Sekty - manipulacja psychologiczna, Gdańsk: GWP.

Abidi J., 2009, Droga do równouprawnienia, w: A. Obem, D. Starzyńska (red.), Architekci zmian: Innowacje dla osób z niepełnosprawnością, Warszawa: Stowarzyszenie Przyjaciół Integracji.

Abu-Rub H., Zabża B., 2002, Status kobiety w islamie, Wrocław: Muzułmańskie Stowarzyszenie Kształtowania Kulturalnego w RP.

Bajcar B., 2001, Różnice międzykulturowe w percepcji czasu $i$ ich znaczenie dla rozumienia efektywności zarządzania, w: M. Strykowska (red.), Współczesne organizacje - wyzwania i zagrożenia. Perspektywa psychologiczna, Poznań: Wydawnictwo Fundacji Humanior.

Boski P., 2006, Męskość-Kobiecość jako wymiar kulturowy. Koncepcje - problemy - pytania - badania, w: A. Chybicka, M. Kaźmierczak (red.), Kobieta w kulturze - kultura w kobiecie, Kraków: Impuls.

Danecki J., 1997, Podstawowe wiadomości o islamie, Warszawa: Wiedza Powszechna.

Goodman N., 1997, Wstęp do socjologii, Poznań: Zysk i S-ka.

Grzesiak H., 2011, Niepełnosprawne kobiety $w$ krajach arabskich $i w$ Indiach, „Niepełnosprawność i Rehabilitacja” nr 2.

Helali M., 2009, Problem autyzmu w Egipcie, w: A. Obem, D. Starzyńska (red.), Architekci zmian: Innowacje dla osób z niepetnosprawnościa, Warszawa: Stowarzyszenie Przyjaciół Integracji.

Januszek H., Sikora J., 1997, Podstawy socjologii, Poznań: Wydawnictwo Akademii Ekonomicznej.

Kłoskowska A., 1983, Socjologia kultury, Warszawa: PWN. 
Kosakowska N., 2006, Kobiety w stereotypowych i niestereotypowych rolach ptciowych Polska i Indie. Porównanie międzykulturowe, w: A. Chybicka, M. Kaźmierczak (red.), Kobieta w kulturze - kultura w kobiecie, Kraków: Impuls.

Kościelniak K., 2006, Chrześcijaństwo w spotkaniu z religiami świata, Kraków: Wydawnictwo M.

Kwiatkowska A., Grzymała-Moszczyńska H., 2008, Psychologia międzykulturowa, w: J. Strelau, J. Doliński (red.), Psychologia. Podręcznik akademicki, Gdańsk: GWP.

Olechnicki K., 1997, Słownik socjologiczny, Toruń: Wydawnictwo Graffiti BC.

Walther W., 1982, Kobieta w islamie, Warszawa: Wydawnictwa Artystyczne i Filmowe.

Wizerunki kobiety w kulturze Indii. Boginie, przadki, wiedźmy i tancerki, 2005, M. Jakubczak (red.), Kraków: Wydawnictwo Universitas.

Zyzik M., 2003, Małżeństwo w prawie muzułmańskim, Warszawa: Elipsa. 